\title{
First records of Periscelididae (Diptera, Opomyzoidea) from French Guiana
}

\author{
Rosaly Ale-Rocha, ${ }^{1,2}$ Matheus M. M. Soares ${ }^{3}$ \\ 1 Coordenação de Biodiversidade, Instituto Nacional de Pesquisas da Amazônia - INPA, Av. André Araújo, Petrópolis, 2936, CEP 69067-375, \\ Manaus, Amazonas, Brazil. 2 Fellowship PQ/CNPq. 3 Programa de Pós-graduaçãodo Instituto Nacional de Pesquisas da Amazônia. \\ Corresponding author: Rosaly Ale-Rocha, alerocha@inpa.gov.br
}

\begin{abstract}
Periscelididae (Diptera, Opomyzoidea) are recorded for the first time from French Guiana, with 5 species Marbenia peculiaris Malloch, 1931, Neoscutops barcelosiensis Ale-Rocha \& Freitas, 2011, Neoscutops flavoscutellatus AleRocha \& Freitas, 2011, Neoscutops peruvianus Hennig, 1969, and Planinasus nigritarsus Mathis \& Rung, 2012 found.
\end{abstract}

\section{Key words}

Neotropical Region; new records; Periscelidinae.

Academic editor: Kirstern Lica Follmann Haseyama | Received 18 April 2018 | Accepted 16 August 2018 | Published 7 September 2018

Citation: Ale-Rocha R, Soares MMM (2018) First records of Periscelididae (Diptera, Opomyzoidea) from French Guiana. Check List 14 (5): 713-720. https://doi.org/10.15560/14.5.713

\section{Introduction}

Periscelididae are a small cosmopolitan family that is more diverse in the Neotropical Region. Representatives of Periscelididae are associated with sap exuding from deciduous trees (Periscelidinae) or with phytotelmata in the axils of monocotyledons (Stenomicrinae) (Mathis and Rung 2011). Information about the immature stages is very scarce and largely from temperate regions (Williams 1939, Teskey 1976, Papp 1988, 1995, 1998). In the Neotropical Region, information on the biological cycle of Stenomicra species associated with Eryngium L. (Apiaceae) in Argentina was provided by Campos et al. (2010). Additionally, Gomes et al. (2018) described a Stenomicra species from material reared in the axils of Alocasia macrorrhizos (L.) G.Don (Araceae) at an urban forest fragment in Brazil.

The family currently comprises about 139 valid species in 10 extant genera and 1 extinct genus (Procyamops, known from Baltic amber); 52 species occur in the Neotropical Region, distributed in 9 genera (Mathis and Rung 2011, Mathis et al. 2012, Rung and Ale-Rocha 2011, Freitas and Ale-Rocha 2011, Ale-Rocha and Freitas 2011, Ale-Rocha et al. 2014).

Here we adopt D.K. McAlpine's $(1978,1983)$ concept of Periscelididae, which includes Cyamops Melander, 1913, Planinasus Cresson, 1914, and Stenomicra Coquillett, 1900, previously allocated to Aulacigastridae. We also adopt the division of the family in 2 subfamilies, Periscelidinae and Stenomicrinae (Grimaldi and Mathis 1993, Baptista and Mathis 1994, Mathis and Papp 1998). Periscelididae flies have broad to slender bodies, body length of $2.5-5 \mathrm{~mm}$, convex and setose face with ventral portion retreated, 1-2 fronto-orbital setae, pedicel caplike with a dorsal cleft, arista bipectinate, postocellar setae divergent or absent, 1 or 2 dorsocentral postsutural setae,vein $\mathrm{C}$ lacking true breaks and extended to vein $R_{4+5}$ or vein $M$, cell dm with a shallow longitudinal fold, vein $\mathrm{CuA}_{2}$ well developed or not completely closing cell 


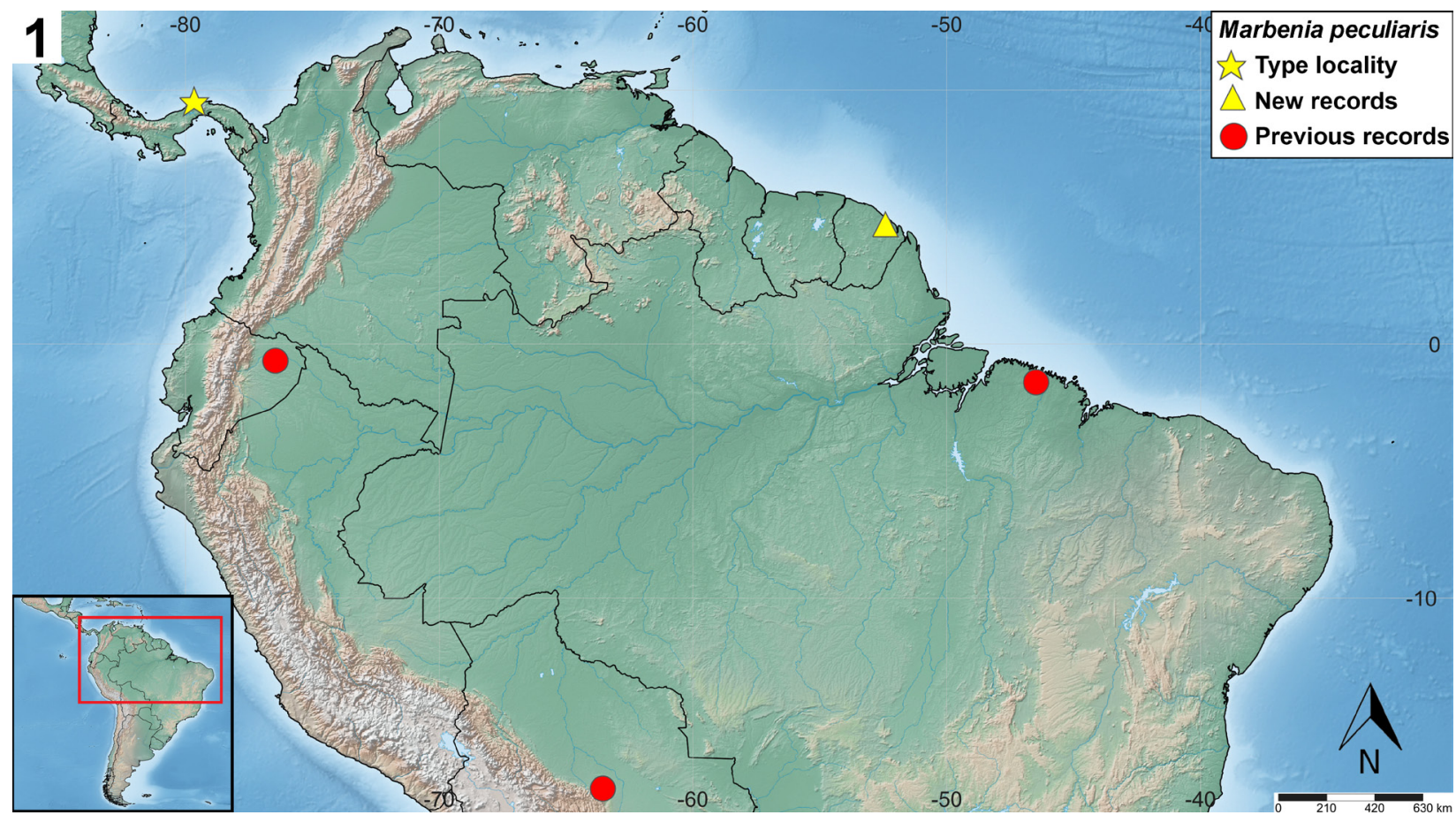

Figure 1. Geographic records of Marbenia peculiaris Malloch, 1931.

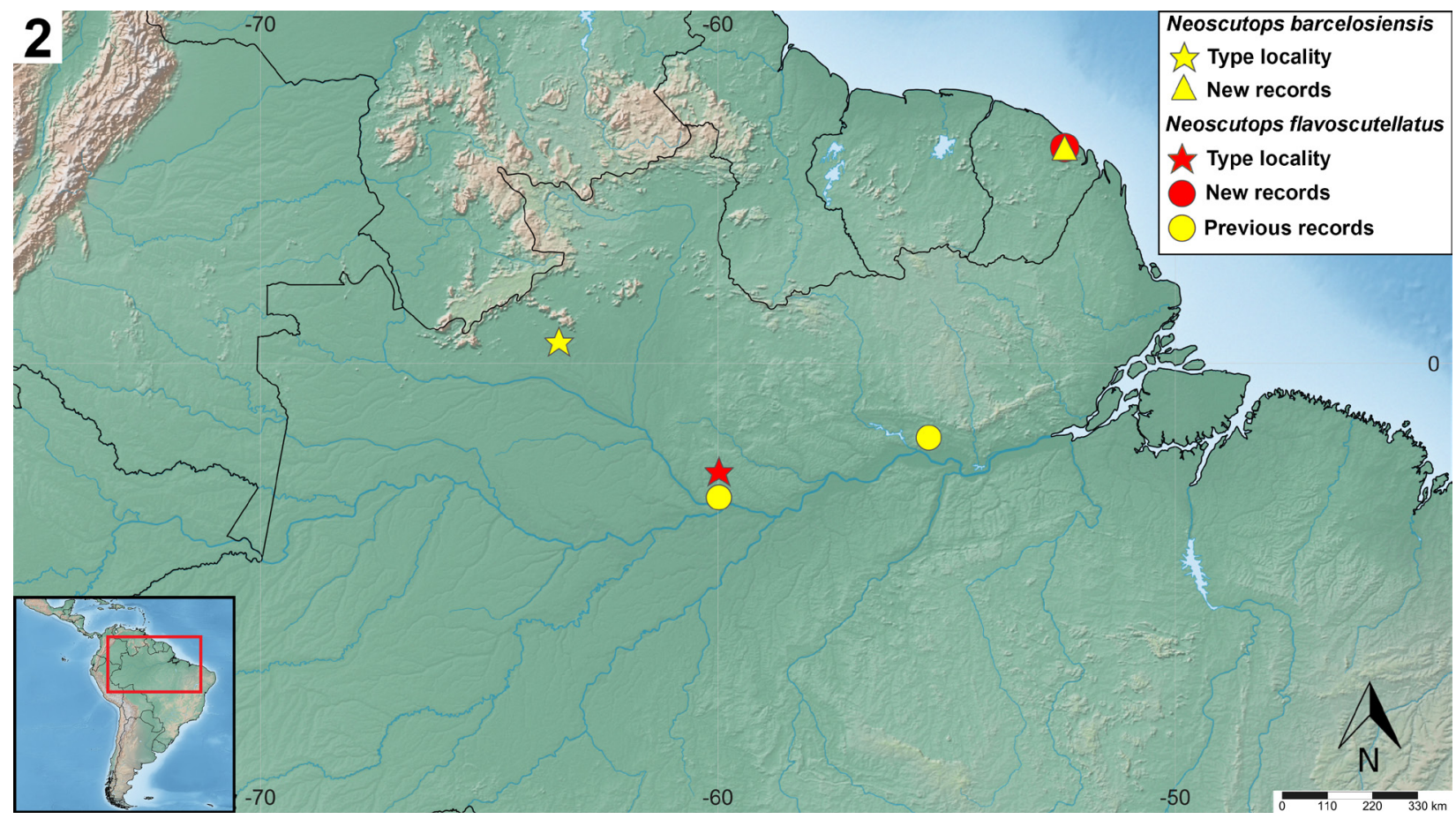

Figure 2. Geographic records of Neoscutops barcelosiensis Ale-Rocha \& Freitas, 2011 and Neoscutops flavoscutellatus Ale-Rocha \& Freitas, 2011.

cup, and mid tibia with 1 apicoventral spine-like seta.

Mathis and Rung (2011) compiled a global catalog of the Periscelididae. In the Neotropical Region, Ale-Rocha and Freitas (2011), Mathis et al. (2012) and Ale-Rocha et al. (2014) revised the Neotropical genera Neoscutops Malloch, 1926, Planinasus Cresson, 1913, and Marbenia Malloch, 1931, respectively.

In this contribution we document the first records of Periscelididae for French Guiana. We provide a list of
Periscelididae species and their known distribution based on the literature, new records and material examined. We also provide maps with the geographic distribution of each species.

\section{Methods}

The material examined belongs to the Natural History Museum (NHMUK), London, United Kingdom. In total 7 specimens were studied. The identification of the mate- 


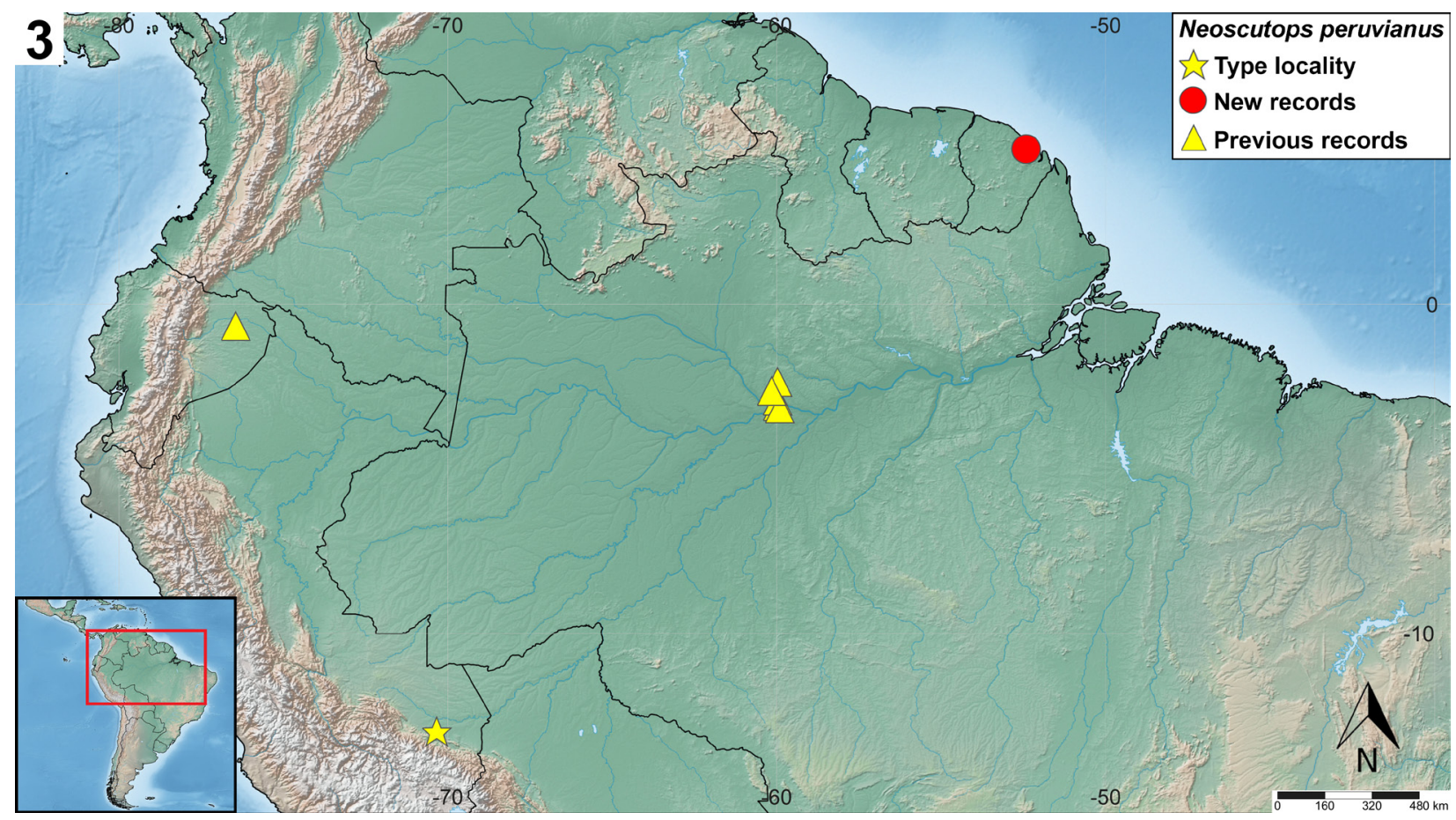

Figure 3. Geographic records of Neoscutops peruvianus Hennig, 1969.

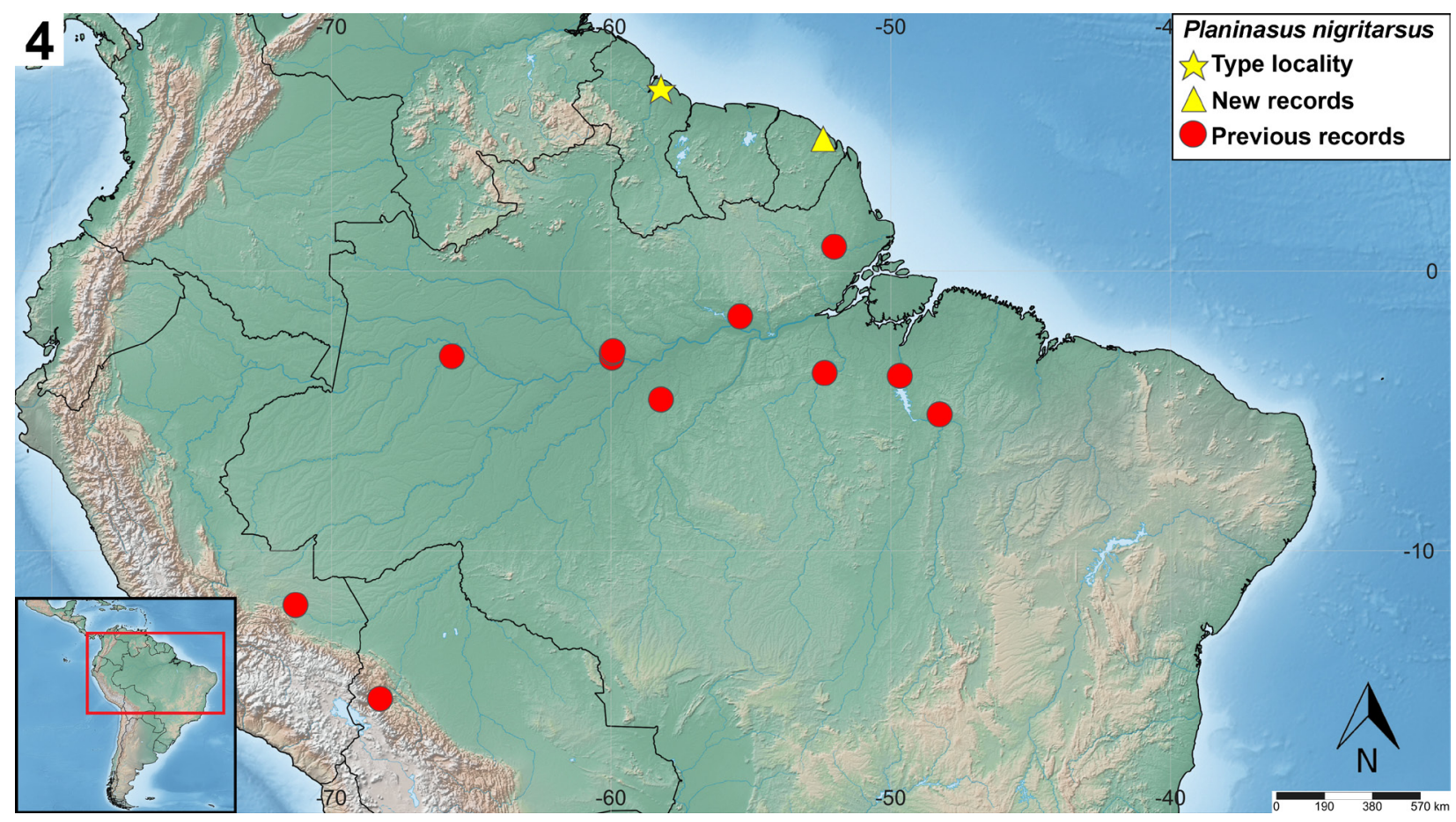

Figure 4. Geographic records of Planinasus nigritarsus Mathis \& Rung, 2012.

rial was made using the taxonomic keys and descriptions provided by Ale-Rocha and Freitas (2011), Freitas and Ale-Rocha (2011), Mathis et al. (2012) and Ale-Rocha et al. (2014).

Specimens were photographed with a Leica MC170 HD camera, attached on a Leica M165 C stereomicroscope. Later, photographs were stacked and combined using Leica Application Suite V4.11. Distribution maps were created with Simplemappr (Shorthouse 2010), using coordinates present on the specimen labels and bibliography.

Morphological terminology for adult structures follows those of Cumming and Wood (2009).

\section{Results}

\section{Marbenia Malloch, 1931}

Diagnosis. Representatives of this genus are character- 

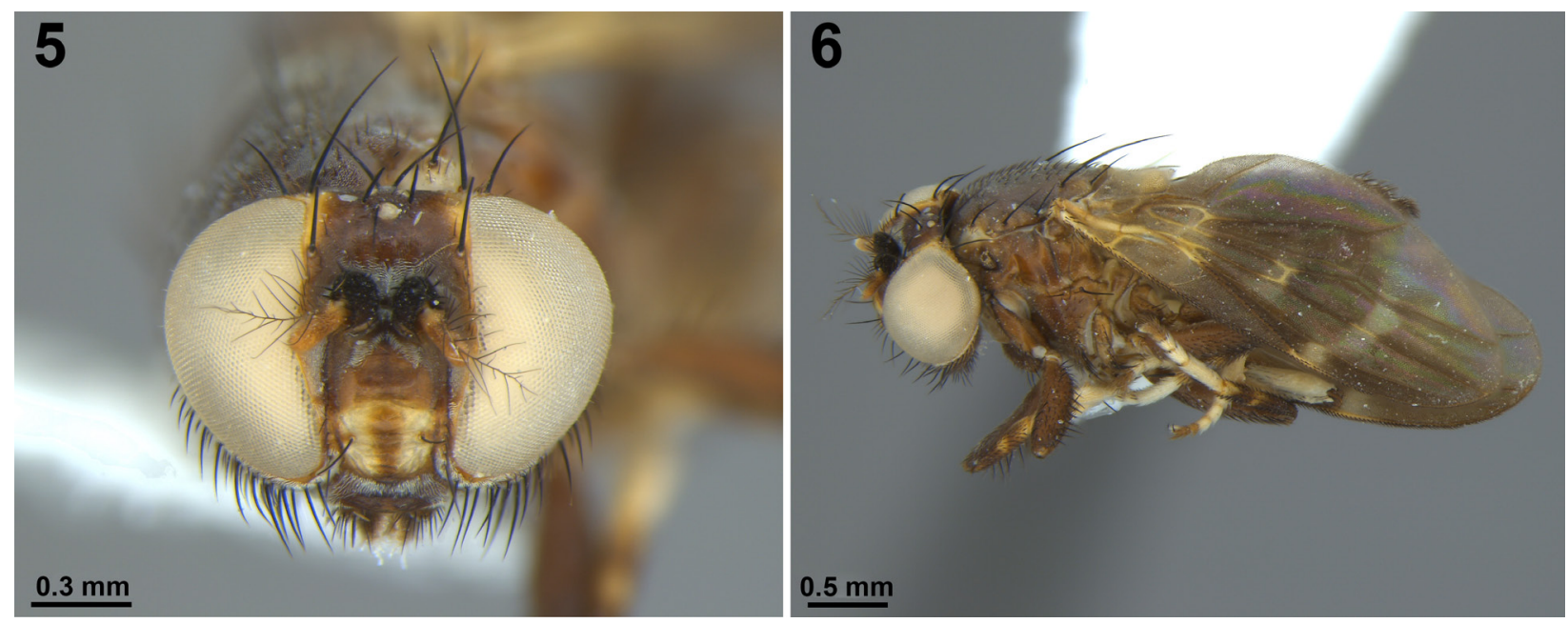

Figures 5, 6. Marbenia peculiaris Malloch, 1931. 5. Head, frontal view. 6. Habitus, lateral.

ized as follows: small flies, body length $2.6-3.5 \mathrm{~mm}$; maxillary palpus short and spatulate; setae of head elongate; postocellar pair well developed; only a pair of setae on facial plate, face with transverse grooves providing a wavy appearance; parafacial, gena, and occiput with numerous strong developed setae; 2 pairs of dorsocentral setae; wing banded; $\mathrm{R}_{1}$ with dorsal setae; $\mathrm{R}_{2+3}$ long and arcuate; $\mathrm{M}$ almost straight; bm-cu complete; $\mathrm{CuA}$ lacking; $\mathrm{A}_{1}+\mathrm{CuA}_{2}$ extended close to wing margin.

Comments. Marbenia occurs only in the Neotropical Region and currently includes 3 species. The genus was revised by Ale-Rocha et al. (2014) and has been previously recorded from Bolivia, Brazil, Ecuador, and Panama.

\section{Marbenia peculiaris Malloch, 1931}

Figs 5, 6

Marbenia peculiaris Malloch 1931: 32, figs 9, 10. Type locality: Porto Bello, Panama. Mathis and Rung 2011: 352 (world catalog); AleRocha et al. 2014 (review).

Diagnosis. Marbenia peculiaris (Figs 5, 6) is easily distinguished from all other species of Marbenia by the following combination of characters: frons brown or pale brown with lateral margins yellow; face brown on upper half, yellow on lower half with a median yellowish brown stripe, not protruded, and with transverse furrows on medial portion; first flagellomere orange; wing predominantly brown, with basal third yellowish, a small hyaline spot on crossvein $\mathrm{r}-\mathrm{m}$ and cell $\mathrm{R}_{2+3}$, and a transverse, narrow, and hyaline band on middle distal third; scutum dark brown with postpronotal lobe and postalar callus yellow, covered with silvery gray pruinescence; scutellum yellow.

New country record. French Guiana, Montagne des Chevaux, ix.2009, window trap, $04^{\circ} 43^{\prime} 00^{\prime \prime} \mathrm{N}, 052^{\circ} 25^{\prime} 00^{\prime \prime}$ W, altitude 90 m, 1 female (NHMUK 0833311).

Geographical distribution (Fig. 1). Bolivia, Brazil (Pará), Ecuador, French Guiana, and Panama (Ale-Rocha et al. 2014).

\section{Neoscutops Malloch, 1926}

Diagnosis. Representatives of this genus are characterized as follows: face convex and setose; ocellar setae weak; 1 pair of fronto-orbital reclinate setae; medial and lateral vertical setae well developed; postocellar setae short and divergent; dorsocentral prescutellar seta 1; wing slightly to strongly infuscate, without pale areas; $\mathrm{R}_{1}$ dorsally setulose; $\mathrm{R}_{2+3}$ long, curved toward costal margin, abruptly curved just beyond $\mathrm{R}_{1}$, and extended very close to Costa; $\mathrm{M}$ arched; bm-cu incomplete; $\mathrm{CuA}_{2}$ incomplete or indistinct; $\mathrm{A}_{1}+\mathrm{CuA}_{2}$ not reaching wing margin.

Comments. Neoscutops is a Neotropical genus comprising 14 species that is known so far only from Brazil, Costa Rica, Ecuador, and Peru. The genus was revised by Ale-Rocha and Freitas (2011).

\section{Neoscutops barcelosiensis Ale-Rocha \& Freitas, 2011} Figs 7, 8

Neoscutops barcelosiensis Ale-Rocha and Freitas 2011: 6, figs 7-10, 52, 63. Type locality: Barcelos, Amazonas, Brazil.

Diagnosis. Neoscutops barcelosiensis (Figs 7, 8) belongs to the peruvianus species group, characterized by palpus long and rectangular, $M$ slightly arched, reaching wing margin before wing apex, Rs strongly sclerotized basally, crossvein $\mathrm{r}-\mathrm{m}$ located beyond middle of upper section of cell $\mathrm{dm}$, and alula with acute apex (Ale-Rocha and Freitas 2011). This species is similar to $N$. annulatus and $N$. manuensis in having a brown to black scutum, but it can be distinguished from them and from the another species of Neoscutops by the brown frons with pale brown to yellow lateral margins, face dark yellow with a brown to black central spot on upper portion, pedicel fully brown, scape and pedicel dark brown, first flagellomere yellow, palpus brown, legs brown, mid and hind tibiae with wide median yellow ring and tarsi whitish-yellow with fifth tarsomere slightly darker.

New country record. French Guiana, Montagne des Chevaux, ix.2009, window trap, $04^{\circ} 43^{\prime} 00^{\prime \prime} \mathrm{N}, 052^{\circ} 25^{\prime} 00^{\prime \prime}$ W, altitude 90 m,1 female (NHMUK 0833304). 


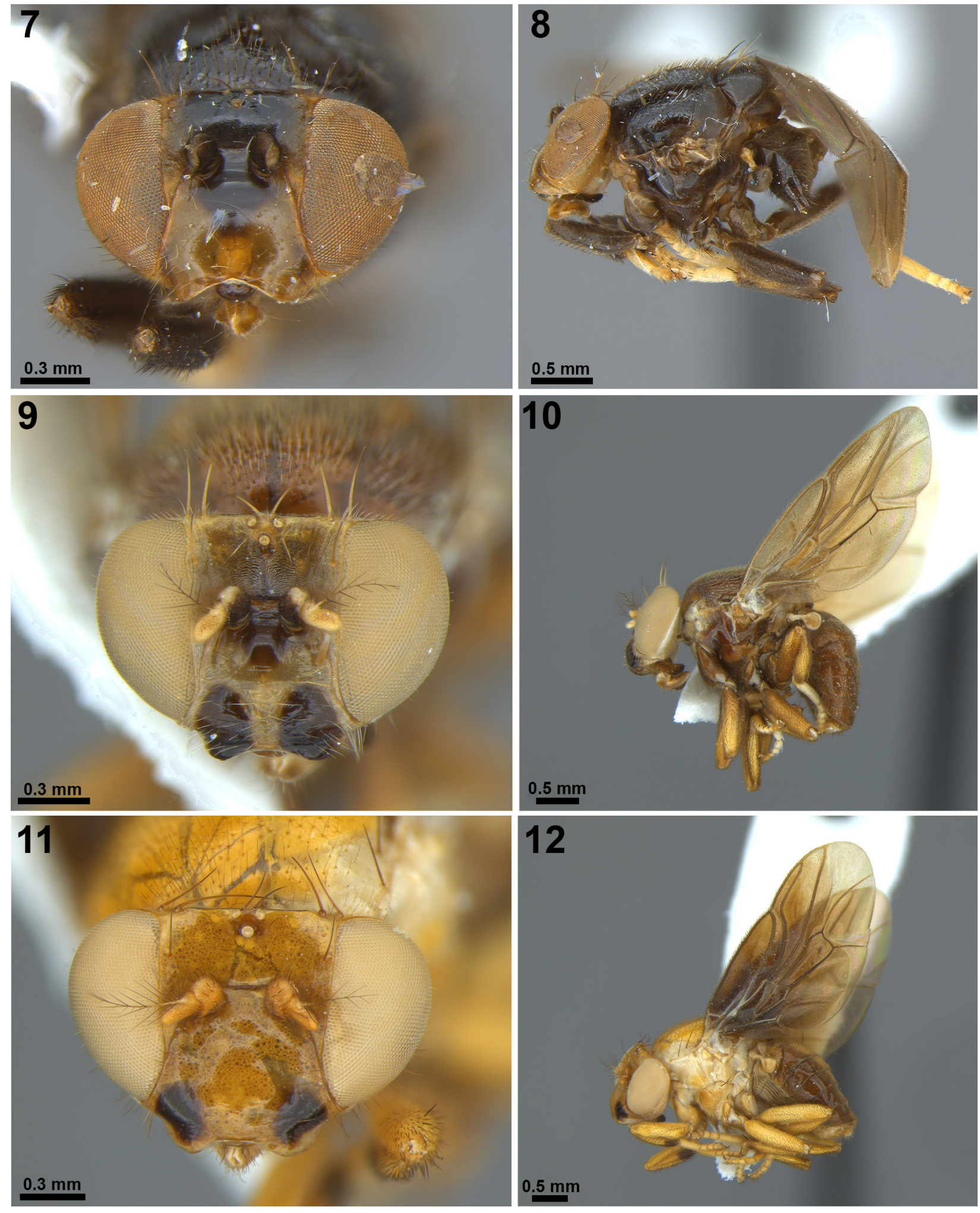

Figures 7, 8. Neoscutops barcelosiensis Ale-Rocha \& Freitas, 2011: (7) head, frontal view; (8) habitus, lateral. 9, 10. Neoscutops flavoscutellatus Ale-Rocha \& Freitas, 2011: (9) head, frontal view; (10) habitus, lateral. 11, 12. Neoscutops peruvianus Hennig, 1969: (11) head, frontal view; (12) habitus, lateral.

Geographical distribution (Fig. 2): Brazil (Amazonas) and French Guiana (Ale-Rocha and Freitas 2011).

\section{Neoscutops flavoscutellatusAle-Rocha \& Freitas, 2011} Figs 9, 10

Neoscutops flavoscutellatus Ale-Rocha and Freitas 2011: 8, figs 11-15, 53, 64. Type locality: Manaus, Amazonas, Brazil.
Diagnosis. Neoscutops flavoscutellatus (Figs 9, 10) belongs to the peruvianus species group (Ale-Rocha and Freitas 2011). This species is similar to N. manaos and $N$. waorani, having the face brown with an inverted W-shaped yellow spot, but can be distinguished from both by the yellow clypeus, scutellum and femora. Additionally, N. flavoscutellatus differs from other species 

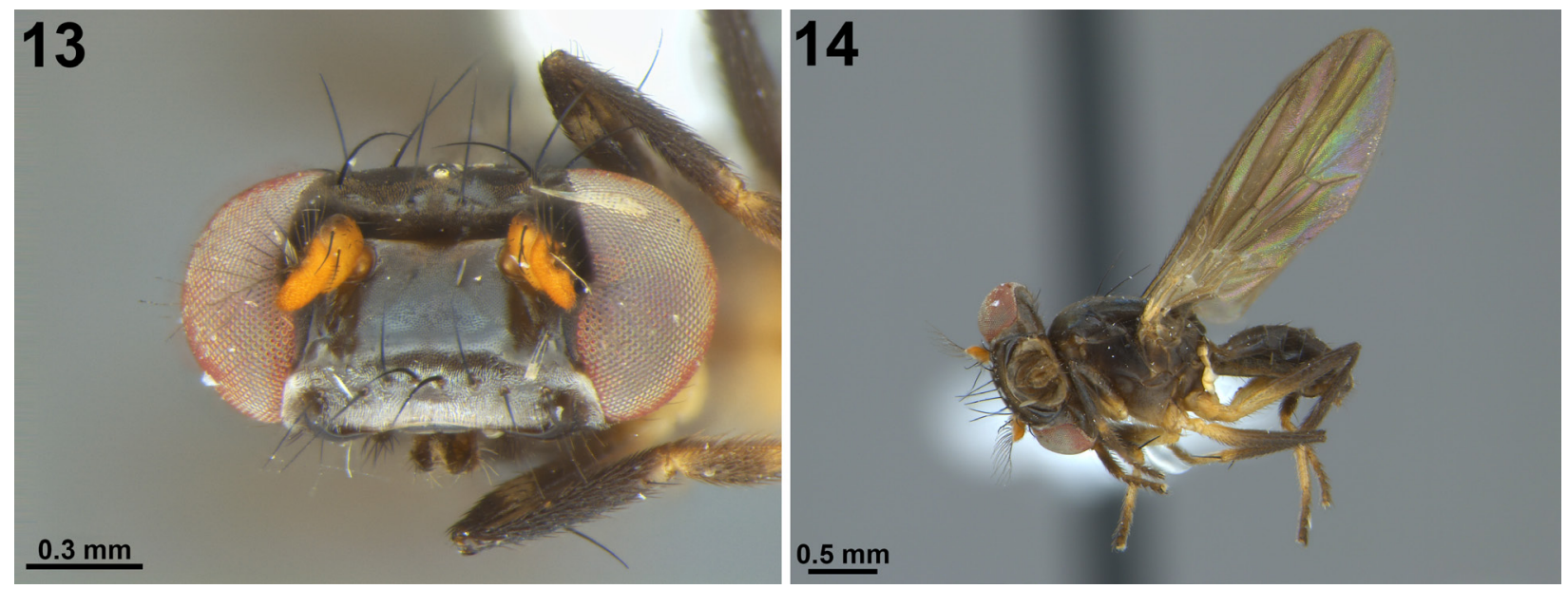

Figures 13, 14. Planinasus nigritarsus Mathis \& Rung, 2012: (13) head, frontal view; (14) habitus, lateral.

of Neoscutops by the color pattern of the face, clypeus and scutellum, as mentioned above, frons pale brown, scape dark brown, pedicel dark brown with whitishyellow dorsoapical spot, first flagellomere pale yellow, palpus brown, scutum brown with postpronotal lobe and postero-lateral margin slightly paler, legs yellow except basal three fourths of fore tibia brown, base and apex of hind tibiae brown.

New country record. French Guiana, Montagne des Chevaux, x.2009, window trap, $04^{\circ} 43^{\prime} 00^{\prime \prime} \mathrm{N}, 052^{\circ} 25^{\prime} 00^{\prime \prime}$ $\mathrm{W}$, altitude $90 \mathrm{~m}, 1$ female (NHMUK 0833306), 1 female (NHMUK 0833307); xi.2009, 1 male (NHMUK 0833308), 1 male (NHMUK 0833309).

Geographical distribution (Fig. 2). Brazil (Amazonas) and French Guiana (Ale-Rocha and Freitas 2011).

\section{Neoscutops peruvianus Hennig, 1969}

Figs 11, 12

Neoscutops peruvianus Hennig 1969: 603. Type locality: Avispas, Madre de Dios, Peru. Mathis and Rung 2011: 352 (world catalog); Ale-Rocha and Freitas 2011: 15-16 (review).

Diagnosis. Neoscutops peruvianus (Figs 11, 12) belongs to the peruvianus species-group. Distinguishing this species from $N$. luteus based on external morphology can be tricky in, but $N$. peruvianus can be differentiated by the yellow scape and pedicel and femora without strong posteroventral setae. In $N$. luteus the scape and pedicel are black, and the forefemur bears short strong posteroventral setae. Neoscutops peruvianus can be distinguished from congenerics by the yellow frons, brown ocellar triangle, yellow face with dark brown rectangular spot on ventral corners, antenna yellow, palpus long and yellow with apical dark brown spot, clypeus yellow, scutum shiny yellow, scutellum and mediotergite brown, legs yellow except for fore tibia dark brown on apical third and mid tibia pale brown on apical fourth.

New country record. French Guiana, Montagne des Chevaux, ix.2009, window trap, $04^{\circ} 43^{\prime} 00^{\prime \prime} \mathrm{N}, 052^{\circ} 25^{\prime} 00^{\prime \prime}$ W, altitude 90 m, 1 female (NHMUK 0833305).
Geographical distribution (Fig. 3). Brazil (Amazonas), Ecuador (Orellana), French Guiana, and Peru (Madre de Dios) (Ale-Rocha and Freitas 2011).

\section{Planinasus Cresson, 1914}

Diagnosis. Planinasus can be distinguished from other genera of Periscelididae as follows: frons with a pair of interfrontal setae, 2 fronto-orbital setae, ocellar setae and postocellar setae absent, basal flagellomere arising from anterior surface of pedicel, costal vein extended to vein $\mathrm{M}$, vein $\mathrm{CuA}_{2}$ present, cell cup distinct, forefemur with 1-3 posteroventral setae on apical half, scutellum bearing only 1 pair of marginal setae, these apical, tibiae with a dorsoapical seta (Mathis et al. 2012). Species of this genus exhibit considerable sexual dimorphism, especially on the width of the body and coloration of the face.

Comments. Planinasus occurs exclusively in the Neotropical Region and currently includes 18 extant and one fossil species. The genus was revised by Mathis et al. (2012) and recoded from Colombia, Belize, Bolivia, Brazil, Costa Rica, Cuba, Dominican Republic, Ecuador, Guatemala, Guyana, Jamaica, Mexico, Panama, Peru, Trinidad and Tobago, and Venezuela.

\section{Planinasus nigritarsus Mathis \& Rung, 2012}

Figs 13, 14

Planinasus nigritarsus Mathis and Rung 2012: 57, figs 65-69. Type locality: Conservation of Ecological Interactions and Biotic Associations (CEIBA), Guyana.

Diagnosis. Planinasus nigritarsus (Figs 13, 14) belongs to the nigritarsus species group together with $P$. argentifacies and $P$. insulanus, sharing a mostly yellowish orange antenna with pedicel and basal flagellomere darkened dorsally, a single transverse row of about 8 large facial setae, and fore femur with 1 large posteroventral seta at apical third (Mathis et al. 2012). Additionally, this species can be distinguished from the latter and from the all other species of Planinasus by the following combination of characters, in addition to the characters of the nigritarsus group: ventral receded portion of face short, 
height shorter than the width of antennal pedicel, and with dense silvery white microtomentum; fore coxa frequently whitish yellow; mid- and hind femora brown with basal third to half yellowish; fore tarsus usually blackish, fore basitarsomere slightly compressed (Mathis et al. 2012).

New country record. French Guiana, Montagne des Chevaux, xi.2009, window trap, $04^{\circ} 43^{\prime} 00^{\prime \prime} \mathrm{N}, 052^{\circ} 25^{\prime} 00^{\prime \prime}$ W, altitude $90 \mathrm{~m}$, 1 female (NHMUK 0833317), male (NHMUK 0833317).

Geographical distribution (Fig. 4). Bolivia (La Paz), Brazil (Amapá, Amazonas, Maranhão, Pará), French Guiana, Guyana, and Peru (Madre de Dios) (Mathis and Rung 2012).

\section{Discussion}

French Guiana is a comparatively small country of 84,000 $\mathrm{km}^{2}$ in northern South America (Brûlé and Touroult 2014) and is part of the Guiana shield in Northern Amazonia (0413' N, 052 ${ }^{\circ} 59^{\prime} \mathrm{W}$ ) (Guitet et al. 2015), bordering with Suriname in the west and with Brazil (Amapá State) in the south and east (Guitet et al. 2013). As part of the large Guiana moist forest ecoregion, French Guiana shares a species pool with adjacent countries (Brûlé and Touroult 2014). Due to the lack of real geographical barriers between French Guiana and neighboring countries (Suriname and Brazil), it is believed that the fauna of French Guiana contains few real endemics (Brûlé and Touroult 2014), as observed for its flora (Granville et al. 1996). In addition, previously known insects from French Guiana are also present in the Amazonian part of Andean countries (Granville 1992).

Five species of Periscelididae were recorded for French Guiana in this paper of which only Marbenia peculiaris was described from a location outside the Amazon sub-region. The type locality of $M$. peculiaris is located in Panama and this species was also recorded from northern Brazil, Ecuador and Bolivia, in the Amazonian biome (Ale-Rocha et al. 2014). All other species here recorded for the first time from French Guiana have their type localities in northern South America, all within the limits of the Amazonian biome. Thus, their occurrence in French Guiana was expected. Here we record for the first time $N$. barcelosiensis and $N$. flavoscutellatus from beyond their type localities. Described from Peru, $N$. peruvianus has also been recorded in Ecuador and Brazil (Ale-Rocha and Freitas 2011), which suggests its distribution may cover the major part of the Amazon. The same can be suggested for Planinasus nigritarsus, which has already been recorded in Bolivia, Peru and northern states of Brazil, all within the Amazon biome (Mathis et al. 2012). Additional collections in neighboring countries may fill the gaps in the distribution of these species and confirm their probable distribution throughout the entire Amazon.

According to Brûlé and Touroult (2014), in their check list of insects of French Guiana, about 15,100 valid species names allocated in 20 orders and 322 families are known in this country and Diptera is one of the poorest studied orders, with only 577 known species. Recently, the fauna of French Guiana has been more intensively studied, greater surveying efforts of the insect fauna have been carried out (Pollet et al. 2014; 2015) and an expressive diversity has been found to other insects (Krolow et al. 2017).

Although this sampling improves our knowledge of Periscelididae, it does not represent the actual diversity of Periscelididae from French Guiana, given the greater diversity of the group in neighboring countries that share the same biome (Ale-Rocha and Freitas 2011, Freitas and Ale-Rocha 2011, Mathis and Rung 2011, Rung and AleRocha 2011, Mathis et al. 2012, Ale-Rocha et al. 2014). Increasing samples from the country will undoubtedly produce a more reliable estimate of the diversity of this family from this part of South America.

\section{Acknowledgments}

We thank Dr Daniel Whitmore (NHMUK), who kindly loaned the specimens used in this study, Conselho Nacional de Desenvolvimento Científico e Tecnológico (CNPq) for the support to the first author through the PQ Fellowship and grant provided to the project Sistemática morfológica de Periscelididae, taxonomia dos gêneros neotropicais e estudos bioecológicos de espécies amazônicas (Diptera, Opomyzoidea), Edital MCTI/ CNPQ/Universal 14/2014, n. 457485/2014-0, and also Coordenação de Aperfeiçoamento de Pessoal de Nível Superior (CAPES) for providing the master scholarship to the second author.

\section{Authors' Contributions}

RAR identified specimens. MMMS produced the photographs and map, edited the manuscript. Both authors wrote the manuscript.

\section{References}

Ale-Rocha R, Freitas G (2011) Revision of the Neotropical genus Neoscutops Malloch (Diptera: Periscelididae). Zootaxa 3016: 1-28. https://doi.org/10.11646/zootaxa.3872.4.3

Ale-Rocha R, Freitas G, Mathis WN (2014) Revision of the Neotropical genus Marbenia Malloch (Diptera: Periscelididae). Zootaxa 3872 (4): 365-375.

https://doi.org/10.11646/zootaxa.3872.4.3

Baptista ARP, Mathis WN (1994) A revision of New World Cyamops Melander (Diptera: Periscelididae). Smithsonian Contributions to Zoology 563: 1-25. https://doi.org/10.5479/si.00810282.563

Brûlé S, Touroult J (2014) Insects of French Guiana: a baseline for diversity and taxonomic effort. ZooKeys 434: 111-130. https://doi. org/10.3897/zookeys.434.7582

Campos RE, Gramajo MC, Lizarralde de Grosso, M (2010) Stenomicra (Diptera: Opomyzoidea) in Argentina, with information on the biology of the genus. Revista de la Sociedad Entomológica Argentina 69 (3-4): 281-285.

Cumming JF, Wood DM (2009) Adult Morphology and terminology. In: Brown BV, Borkent A, Cumming JM, Wood DM, Woodley NE, 
Zumbado MA (Eds) Manual of Central America Diptera. Vol. 1. Research Press, Ottawa, 9-64.

Freitas G, Ale-Rocha R (2011) Description of two new species of Stenomicra Coquillett (Diptera, Periscelididae) from the Neotropics. Revista Brasileira de Entomologia 55 (3): 348-354. https:// doi.org/10.1590/S0085-56262011005000044

Gomes ES, Ale-Rocha R, Keppler, RLF (2018) A new species of Stenomicra Coquillett (Diptera: Periscelididae) from the Brazilian Amazon and its life history. Zootaxa 4407 (4): 591-599. https://doi org/10.11646/zootaxa.4407.4.11

Granville JJ de (1992) Un cas de distribution particulier: les espèces forestières péri-amazoniennes. Compte rendu des séances de la société de biogéographie 68: 1-33. http://www.documentation.ird. fr/hor/fdi:34638

Granville JJ de, Cremers G, Hoff M (1996) L'endémisme en Guyane française. In: Guillaumet JL, Belin M, Puig H (Eds) Phytogéographie Tropicale: Colloque International en Hommage au Professeur Raymond Schnell, 1993/07/06-08. ORSTOM, Paris, 101-113. http://herbier.unistra.fr/uploads/media/endemisme_guyane.pdf

Grimaldi DA, Mathis WN (1993) Fossil Periscelididae (Diptera). Proceedings of the Entomological Society of Washington 95: 383-403.

Guitet S, Cornu JF, Brunaux O, Betbeder J, Carozza JM, Richard-Hansen C (2013) Landform and landscape mapping, French Guiana (South America). Journal of Maps 9: 325-335. https://doi.org/10. 1080/17445647.2013.785371

Guitet S, Pélissier R, Brunaux O, Jaouen G, Sabatier D (2015) Geomorphological landscape features explain floristic patterns in French Guiana rainforest. Biodiversity and Conservation 24:1215-1237. https://doi.org/10.1007/s10531-014-0854-8

Hennig, W (1969) Newe Gattungen und Arten der Acalyptratae. Canadian Entomologist 101 (6): 589-633.

Krolow TK, Henriques AL, Pollet M (2017) The Tabanidae of the Mitaraka expedition, with an updated check list of French Guiana (Diptera). ZooKeys 684: 85-118. https://doi.org/10.3897/zookeys.684.13197

Malloch JR (1931) Notes on some acalyptrate flies in the United States National Museum. Proceedings of the United States National Museum 78 (15): 1-32. https://doi.org/10.5479/si.00963801.78-2858.1

Mathis WN, Papp L (1998) Family Periscelididae. In: Papp L, Darvas B (Eds) Manual of Palaearctic Diptera Vol. 3. Science Herald, Buda- pest, 285-294.

Mathis WN, Rung A (2011) World catalog and conspectus on the family Periscelididae (Diptera: Schizophora). Myia 12: 341-377.

Mathis WN, Rung A, Kotrba M (2012) A revision of the genus Planinasus Cresson (Diptera, Periscelididae). ZooKeys 225: 1-83. https:// doi.org/10.3897/zookeys.225.3721

McAlpine DK (1978) Description and biology of a new genus of flies related to Anthoclusia and representing a new family (Diptera, Schizophora, Neurochaetidae). Annalsofthe Natal Museum 23 (2): 273-295.

McAlpine DK (1983) A new subfamily of Aulacigastridae (Diptera: Schizophora), with a discussion of aulacigastrid classification. Australian Journal of Zoology 31: 55-78.

Papp L (1988) Perisceliskabulisp. n. and P. kaszabisp. n. with notes on larvae and pupae of the families Aulacigastridae and Periscelididae (Diptera). Acta Zoologica Academiae Scientiarum Hungaricae 34: 273-284.

Papp L (1995) Morphology of Periscelisannulata third instar larva and Turanodinia tisciae larva and puparium (Diptera: Periscelididae and Odiniidae). Acta Zoologica Academiae Scientiarum Hungaricae 41: 15-24.

Papp L (1998) Life-habits of the Central European species of Periscelididae (Diptera). Folia EntomologicaHungarica 59: 119-123.

Pollet M, Pascal O, Touroult J (2014) Flies from French Guiana: a unique opportunity. Fly Times 53: 3-6.

Pollet M, Touroult J, Pascal O (2015) Preliminary results of the Mitaraka expedition (French Guiana). Fly Times 55: 3-10.

Rung A, Ale-Rocha R (2011) New species of Cyamops (Diptera: Opomyzoidea: Periscelididae) from the old and new world tropics. Zoologia 28 (6): 803-811. https://doi.org/10.1590/S1984-4670201 1000600014

Shorthouse DP (2010) SimpleMappr, an online tool to produce publication-quality point maps. http://www.simplemappr.net. Accessed on: 2017-12-20.

Teskey HJ (1976) Diptera larvae associated with trees in North America. Memoirs of the Entomological Society of Canada 100: 1-53.

Williams FX (1939) Biological studies in Hawaiian Water-Loving Insects. Part III. Diptera of flies. B. Asteiidae, Syrphidae and Dolichopodidae. Proceedings of the Hawaiian Entomological Society 10: 281-315. 